\title{
The irregular pattern of isotopic and ionic signals in the typical monsoon temperate-glacier area, Yulong mountain, Ghina
}

\author{
HE Yuanoing, ${ }^{1}$ Wilfred H. THEaKSTOne, ${ }^{2}$ YAO Tandong, ${ }^{1}$ CHEN Tuo, ${ }^{1}$ David D. ZHANG ${ }^{3}$ \\ ${ }^{1}$ Cold and Arid Regions Environmental and Engineering Institute, Chinese Academy of Sciences, Lanzhou 730000, China \\ E-mail:yqhe@ns.lzb.ac.cn \\ ${ }^{2}$ Department of Geography, University of Manchester, Manchester M13 9PL, England \\ ${ }^{3}$ Department of Geography, University of Hong Kong, Hong Kong, China
}

\begin{abstract}
Sampling was carried out at Baishui glacier No. 1, the largest glacier on Yulong mountain, China, during the summers of 1999 and 2000, to investigate the spatial variations of oxygen isotopes in the atmosphere-glacier-river system. The results confirm that there is an apparent inverse relation between the oxygen isotopic composition of precipitation and air-temperature/precipitation amount in this region, with lower $\delta^{18} \mathrm{O}$ values when the amount of precipitation and air temperature in summer is higher, due to the influence of intense monsoon climate on the study area. There are marked differences in the $\delta^{18} \mathrm{O}$ values of winter-accumulated snow, glacial meltwater, summer precipitation and the glacier-fed river water. Spatial and temporal variations of isotopic composition are controlled by varied weather conditions at different altitudes. Isotopic depletion or fractionation occurs during phase changes, snow-to-ice and ice-to-meltwater transformations and runoff processes. Variations of stable isotopes in glacier runoff can indicate variations of sources of supply. Ionic changes occur as a result of meltwater contact with glacier bed materials.
\end{abstract}

\section{INTRODUGTION}

Stable isotopes and ions are useful tracers in glaciological and hydrological research (Dansgaard, 1964; Moser and Stichler, 1980; Stichler, 1987; Wagenbach, 1989; Kendall and McDonnell, 1998). They provide information about the influence of atmospheric circulation patterns on the chemical composition of the snowpack (He and Theakstone, 1994), changes of snowpack chemistry through the melting period (Shanley and others, 1995; Raben and Theakstone, 1998; He and others, 2001a, b), the contributions made by snow, ice and rainfall to glacier-river discharge (Theakstone, 1988; Theakstone and Knudsen, 1989), and the water entering the system from glacier surface, in-glacial and subglacial drainage systems (Theakstone and Knudsen, 1996; Tranter and others, 1996).

Stable-isotope studies have been carried out on the Qinghai-Tibetan Plateau since the early 1990s (Yao and others 1991; Zhang and Yao, 1995; Tian and others, 1997). On the precipitation-rich part of the southern Qinghai-Tibetan Plateau, especially in the intense-monsoon-climate stable isotopes in precipitation (represented by $\delta^{18} \mathrm{O}$ values), precipitation amount and air temperature are inversely related. The amount of precipitation is higher in summer, as air masses mainly originate from moisture-rich maritime sources. They become more depleted of heavy isotopes along the transportation routes from ocean to continental precipitation sites.
Thus, the lower stable-isotopic values correspond to higher precipitation amount and high temperature in summer (Dansgaard, 1964; Rozanski and others, 1993). In winter, however, when air masses mainly come from closer continental sources, precipitation amount and temperature are lower, and the $\delta^{18} \mathrm{O}$ values of precipitation are higher. Kang and others (2000) noted that the irregular pattern of isotopes of precipitation is dominant in the Himalaya and southern regions of the Qinghai-Tibetan Plateau. In contrast, there is a marked positive correlation between the $\delta^{18} \mathrm{O}$ values of precipitation and air temperature on the northern part of the plateau, where air masses for precipitation mainly originate from continental sources (Hou and others, 1999). Air temperature appears to be the controlling factor in temporal fluctuations of $\delta^{18} \mathrm{O}$ values in the northeastern part of the plateau (Kang and others, 2000).

Twenty-two per cent of the glaciers in the large glaciercovered areas of western China are temperate glaciers ("maritime-type glaciers"), but few studies have been made of stable isotopes in China's monsoon temperate-glacier region. In order to fill the gap, the first research programme of ice-core drilling at Baishui glacier No. 1 was carried out in summer 1999 (He and others, 2000). The isotopic variations down to a below-surface depth of $7.8 \mathrm{~m}$ correlate roughly with variations of winter temperature and precipitation in the most recent 5 years (He and others, 2000). At the same time as the coring was carried out, samples of accumulated 


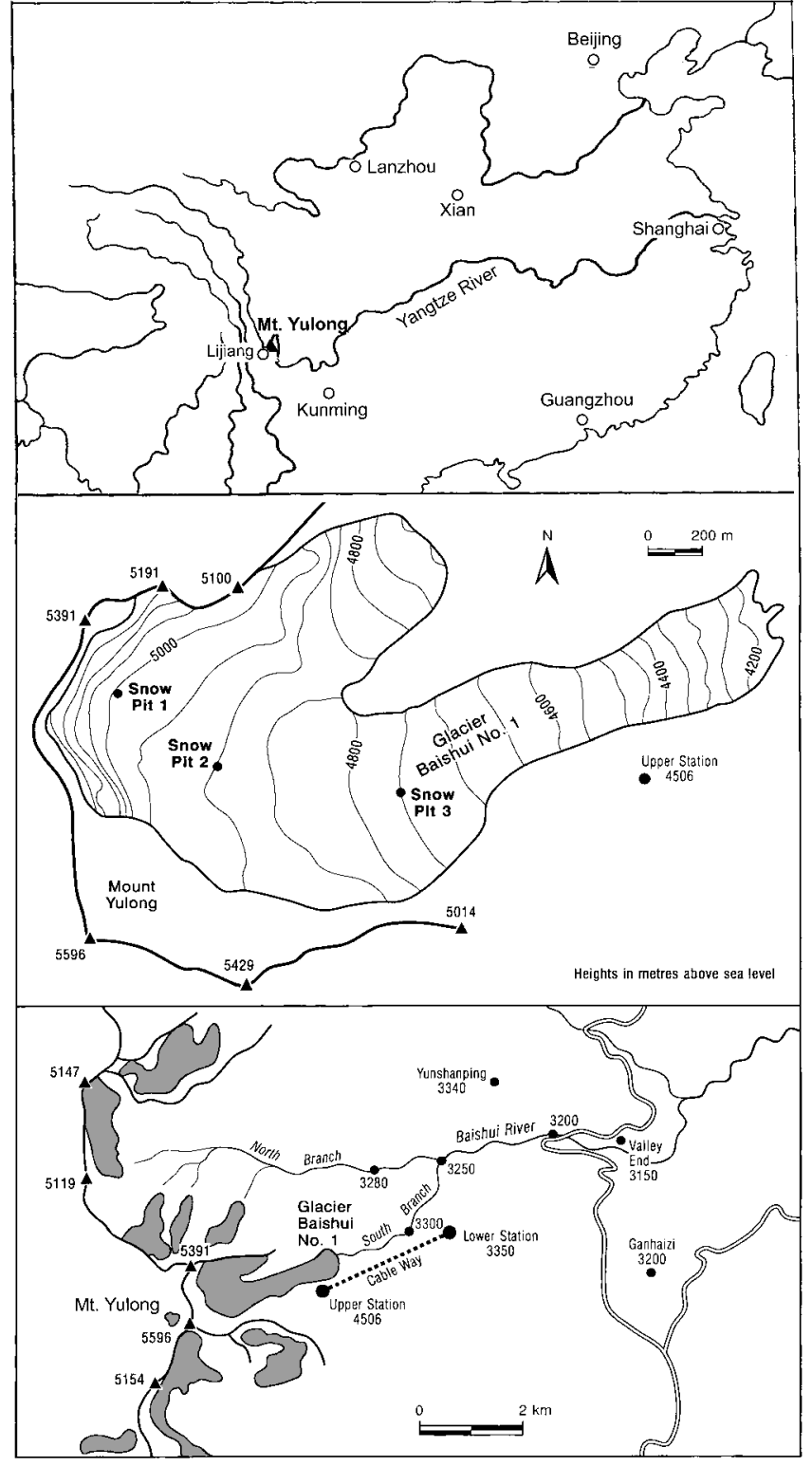

Fig 1. Sketch maps indicating the location of Yulong mountain in southeastern Asia (a), Baishui glacier No. 1, with the locations of snow pits used in 2000 (b), and the area around Yulong mountain, with precipitation and river-water sampling sites (c).

snow, glacial meltwater, summer rain and glacier-fed river water were collected at and around the glacier. Investigations were continued in July 2000, when more detailed sampling was undertaken. The results of investigations in both 1999 and 2000 are reported and discussed here.

\section{GENERAL SITUATION IN THE STUDY AREA}

Yulong mountain, located in the Hengduan range (southeastern edge of the Qinghai-Tibetan Plateau), north of Lijiang, Yunnan province, China $\left(27^{\circ} 10^{\prime}-27^{\circ} 40^{\prime} \mathrm{N}, 100^{\circ} 07^{\prime}-\right.$ $100^{\circ} 10^{\prime} \mathrm{E}$ ), is the southernmost glacierized area in Eurasia (Fig. 1). The climate of the high-altitude area $(>4100 \mathrm{~m}$ a.s.l.) on Yulong mountain, which is controlled by the South Asia/Indian monsoon, has provided the cold, moist conditions necessary for glacier development. The 19 glaciers on Yulong mountain cover $11.61 \mathrm{~km}^{2}$. Their high accumulation and ablation, high temperatures, basal sliding and rapid move- ment are typical of subtropical temperate glaciers $(\mathrm{Li}$ and $\mathrm{Su}$, 1996). The largest glacier, Baishui No. 1 , has an area of $1.52 \mathrm{~km}^{2}$ and is $2.7 \mathrm{~km}$ long (Fig. 1). Its broad, flat accumulation area covers about $1.0 \mathrm{~km}^{2}$ at $4800-5000 \mathrm{~m}$ a.s.l. The glacier terminates at about $4150 \mathrm{~m}$ a.s.l.. Its tongue is heavily crevassed, reflecting very active motion. Glacial meltwater flows to the Baishui river, within the upper Yangtse river basin.

Yulong mountain, with a highest peak, Satseto, of $5596 \mathrm{~m}$, is in the subtropical zone. Seventy per cent of the region's precipitation falls between June and September from the warm, moisture-rich air masses of the prevailing southwestern summer monsoon from the Indian Ocean. In winter, the climate is relatively dry, controlled by the winter monsoon of closer continental origin. The multi-year mean annual precipitation at Lijiang meteorological station (2393 ma.s.l.) is $772 \mathrm{~mm}$, and the 4 year average at the mountain foot ( $3240 \mathrm{~m}$ a.s.l.) is $1646 \mathrm{~mm}$ ( $\mathrm{Su}$ and $\mathrm{Pu}, 1996$ ). A snow-firn core acquired in 1999 at around $4950 \mathrm{~m}$ a.s.l. indicated a 4 year mean annual net accumulation of $900 \mathrm{~mm}$ w.e. (He and others, 200la). Since the measured net accumulation is the only data obtained in relation to the atmospheric precipitation above $4800 \mathrm{~m}$ a.s.l. on Yulong mountain, it is assumed to represent an "average" rate in the glacier's accumulation area, although values at other sites may be different. Using the mean net accumulation rate recovered in the core, together with the ablation rates measured by Su and Wang (1996), the estimated mean annual precipitation in the accumulation area ( $>4800 \mathrm{~m}$ a.s.l.) of the glacier is $2400-3100 \mathrm{~mm}$ ( $\mathrm{He}$ and others, 2001b). However, the precipitation in the glacier's ablation area at $4150-4800 \mathrm{~m}$ a.s.l. is still unknown. The mean annual temperature at Lijiang is $12.6^{\circ} \mathrm{C}$, with a positive mean temperature in every month. At $5400 \mathrm{~m}$ a.s.l. the mean annual temperature is about $-7.5^{\circ} \mathrm{C}$, and all monthly mean temperatures are $<0^{\circ} \mathrm{C}$. The mean annual temperature above the equilibrium line $\left(4800-5000 \mathrm{~m}\right.$ a.s.l.) is $-3.3^{\circ}$ to $-4.7^{\circ} \mathrm{C}$ (Wang, 1996). This suggests an adiabatic lapse rate of about $0.7^{\circ} \mathrm{C}$ per $100 \mathrm{~m}$, which is higher than that for a pure maritime area because Yulong mountain is distant from the Indian Ocean, under the monsoon climate of wetter summers but drier winters.

\section{RESULTS AND DISGUSSION}

In July 1999, samples of recently deposited snow, summer rain, supraglacial and subglacial meltwater were collected from Baishui glacier No. 1, and river water samples were collected from the glacier-fed Baishui river. The samples were collected at the field sampling sites (Fig. 1). Each sample of snow and ice was melted at about $20^{\circ} \mathrm{C}$ in a clean plastic $\mathrm{bag}$, and the meltwater and other water samples were poured into pre-cleaned high-density polyethylene bottles; the bottle top was sealed with wax to prevent evaporation or diffusion. Bottled samples were transported to the Laboratory of Ice Core and Cold Regions Environment, Chinese Academy of Sciences, and kept in a cold room at $-20^{\circ} \mathrm{C}$ until $\delta^{18} \mathrm{O}, \mathrm{Na}^{+}$, $\mathrm{Ca}^{2+}, \mathrm{Mg}^{2+}, \mathrm{Cl}^{-}$, conductivity and $\mathrm{pH}$ values were determined using a Finngan MAT-252 Spectrometer (precision 0.5\%o), Dinex-100 chromatography (precision $0.1 \%$ ), a 2380 Atomic Absorption Spectrophotometer (precision 0.2\%), conductivity and $\mathrm{pH}$ meters. The results are shown in Figures 2-4.

The $\delta^{18} \mathrm{O}$ values of the three samples of snow deposited during the same winter that were collected above the 

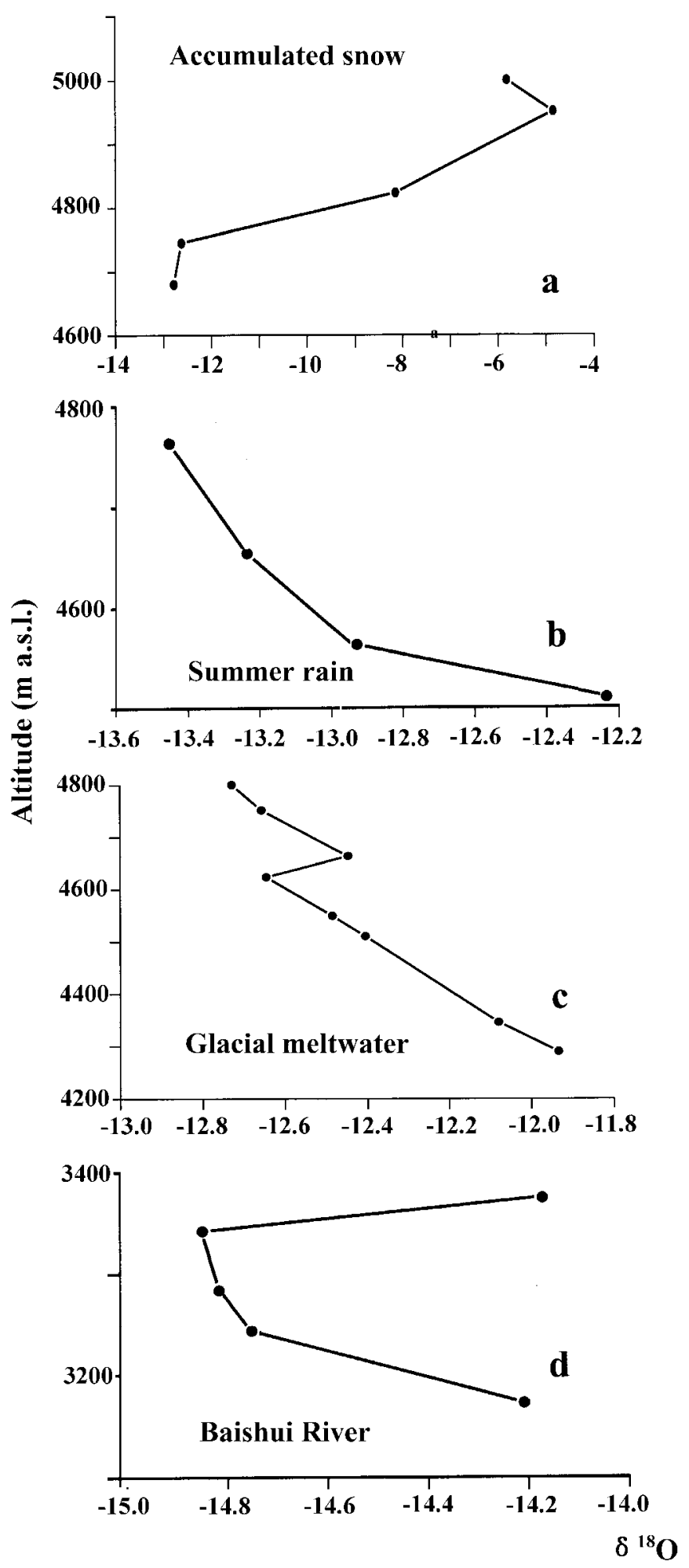
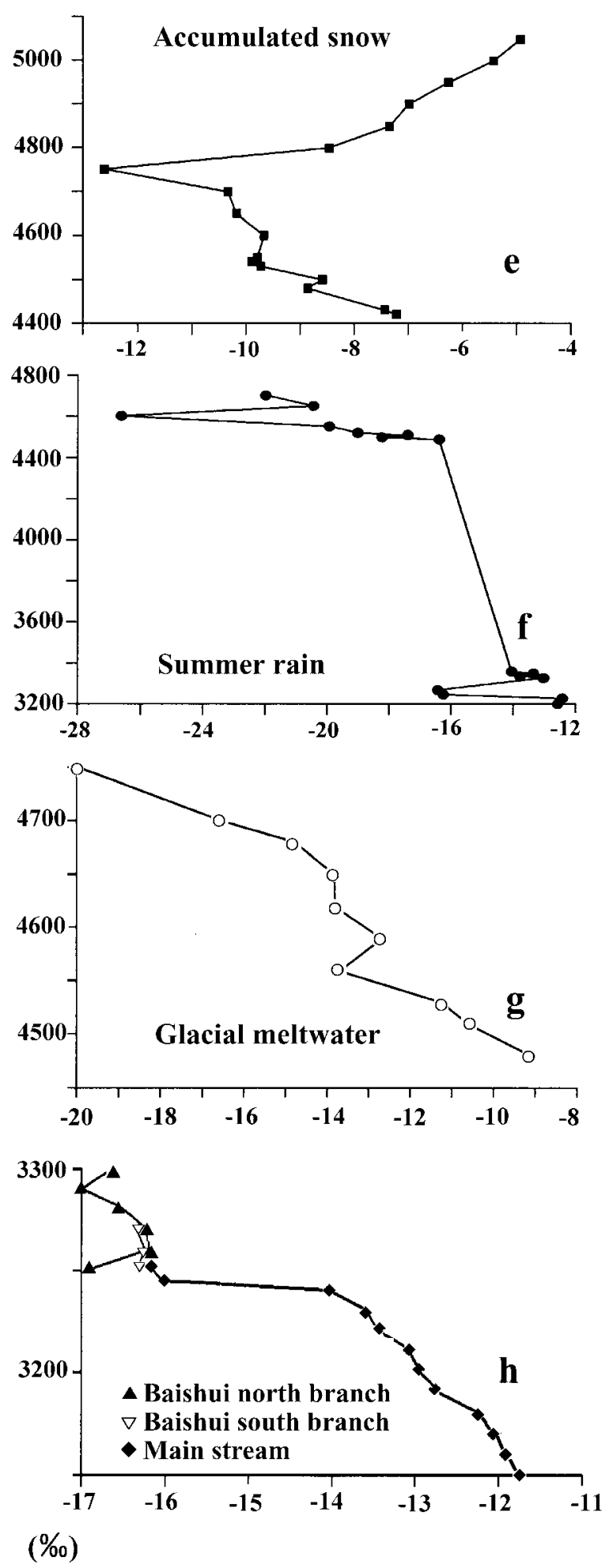

Fig. 2. Altitudinal variations of $\delta^{18} \mathrm{O}$ values in accumulated snow, summer rainfall and glacial meltwater at Baishui glacier No. 1 , and in glacier-fed river water, Fuly $1999(a-d)$ and fuly $2000(e-h)$.

equilibrium line $(4800 \mathrm{~m})$ were much higher than those of the two samples collected below it (Fig. 2). These highaltitude winter-deposited snow samples were more enriched in the heavy isotope than any other samples (e.g. recently deposited (1 month) snow and summer rain) obtained during the 1999 study. The general increase of $\delta^{18} \mathrm{O}$ values with altitude (Fig. 2) indicates an irregular and varied spatial pattern, contrasting with the situation in the northern Qinghai-Tibetan plateau (Yao and others, 1991), in this monsoon-dominated region.

Four samples of summer rainfall were collected at
Baishui glacier No. 1 during a single precipitation event in July 1999. There was a trend of increasing $\delta^{18} \mathrm{O}$ values with decreasing elevation (Fig. 2), but the range was low (1.23\%o). The $\delta^{18} \mathrm{O}$ values of precipitation samples collected during a single event may differ, and their average value depends strongly on the meteorological situation at different altitudes of the air in which it is produced and through which it falls (Rozanski and others, 1993). Accordingly, the slight differences of $\delta^{18} \mathrm{O}$ values in this single summer rain event are caused by the different climatic conditions at varied elevations. A decrease in $\delta^{18} \mathrm{O}$ values with rising altitude 

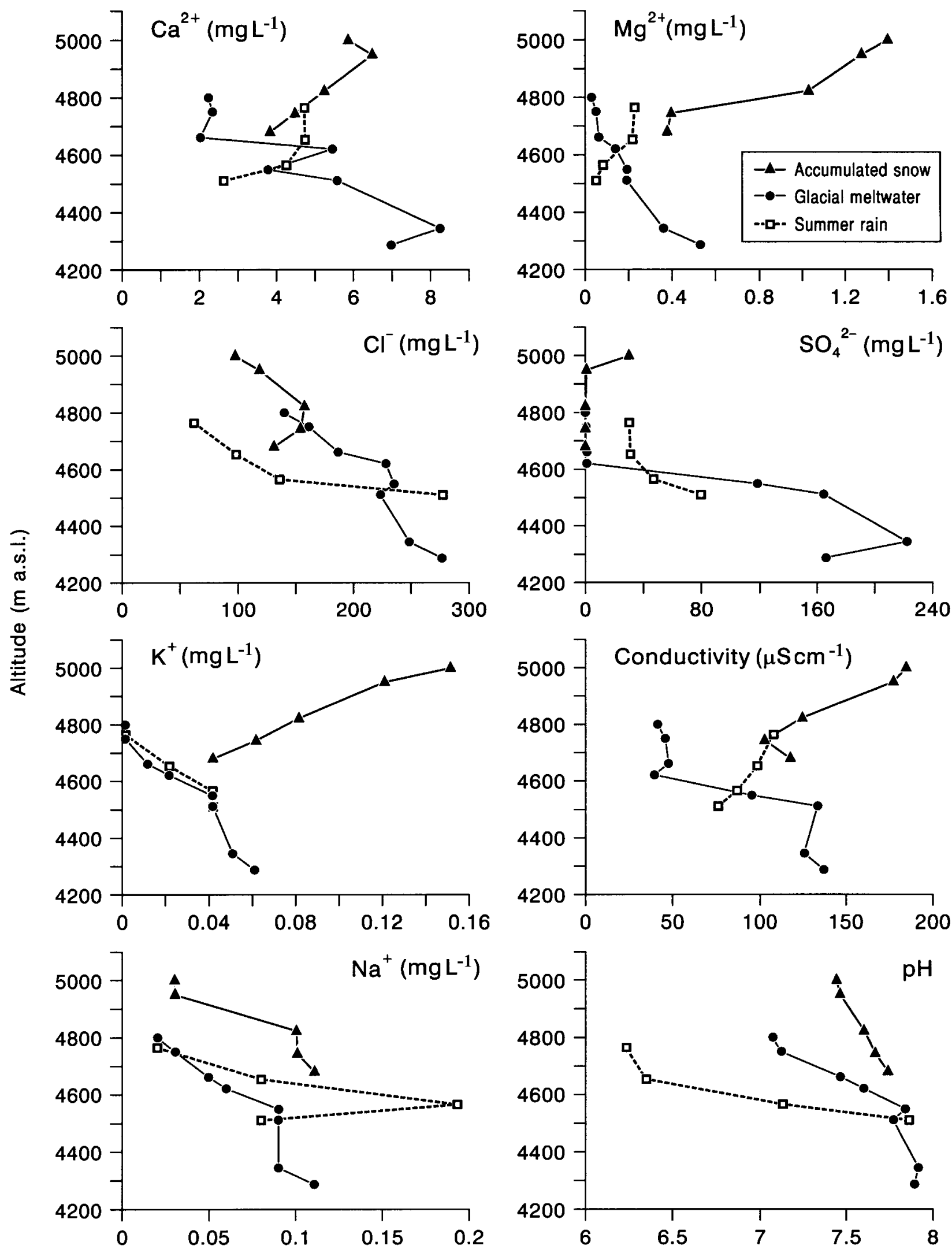

Fig. 3. Altitudinal variations of $\mathrm{Ca}^{2+}, \mathrm{Cl}, \mathrm{K}^{+}, \mathrm{Na}^{+}, \mathrm{Mg}^{2+}, \mathrm{SO}_{4}^{2}$, conductivity and $\mathrm{pH}$ values in accumulated snow, summer rainfall and glacial meltwater at Baishui glacier No. 1, July 1999.

corresponds to an increase in precipitation amount and a decrease in temperature with increasing altitude, indicating a complicated isotopic variation during the single precipitation.

Eight meltwater samples were collected in the glacier's ablation area. Their $\delta^{18} \mathrm{O}$ values tended to increase with decreasing altitude, but the range was small $(0.80 \%$ o). In general, the samples were less depleted of ${ }^{18} \mathrm{O}$ than were the rainfall samples (Fig. 2). The $\delta^{18} \mathrm{O}$ values of the samples from the Baishui river varied only slightly from a mean of $-14.56 \%$, suggesting that glacial meltwater was mixed with water which was more depleted of the heavy isotope.

Variations of dissolved ions in the different sources of supply to, and output from, a glacio-hydrological system reflect their different origins. Most of the ions in the 


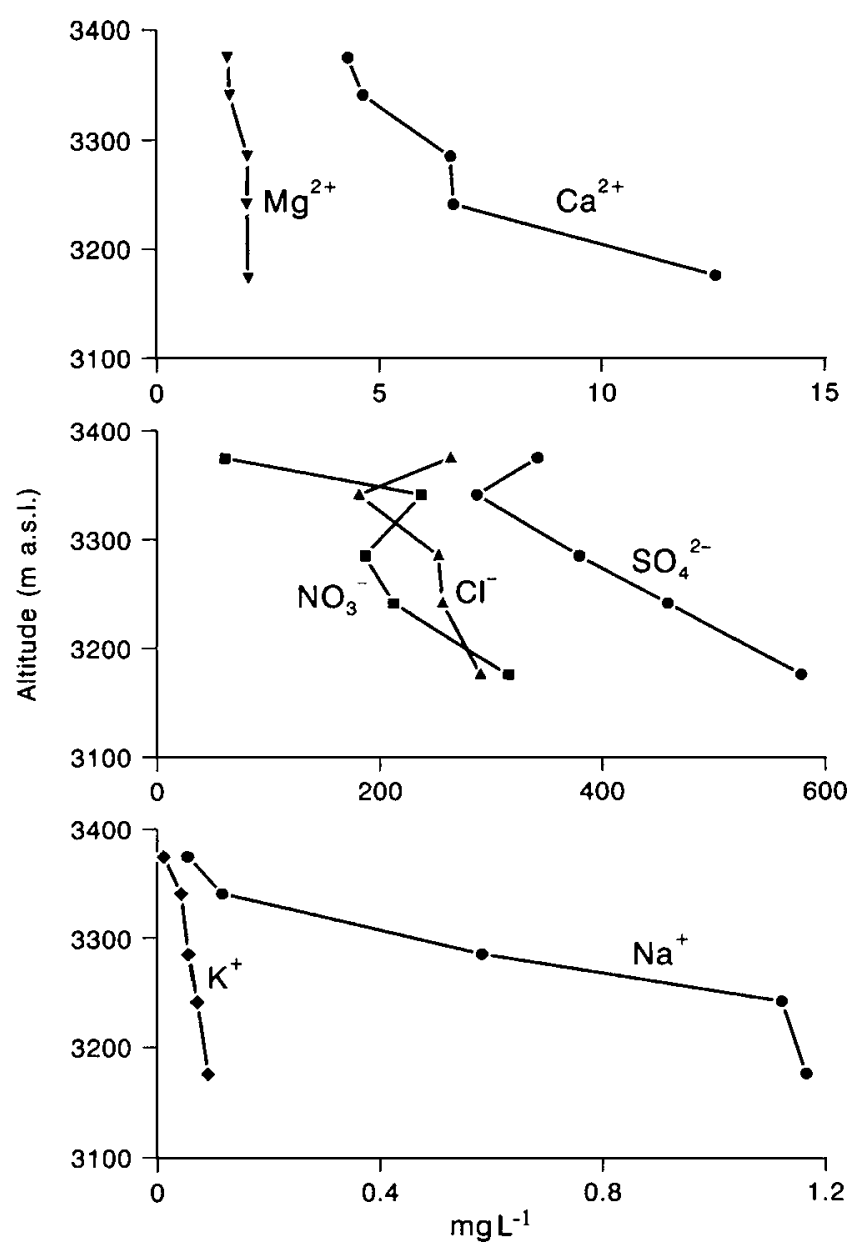

Fig. 4. Ionic variations in the glacier-fed Baishui river, Fuly 1999.

accumulation area of Baishui glacier No. 1 probably came from nearby sources: (1) wind-blown crustal materials from the mountain slopes, (2) impurities carried by moist air moving up the slopes, (3) avalanches from the valley walls, and (4) contact with the glacier bed by flowing ice and meltwater. Ionic concentrations in rainwater were low, particularly at high altitude (Fig. 3), and it is apparent that the impurity content of the precipitation falling on Baishui glacier No. 1 was small. Solutes are acquired by meltwater and glacier river water as a result of contact with other sources. The increase in contact area between meltwater and the glacier bed with decreasing altitude led to higher ionic concentrations in the meltwater and the Baishui river (Figs 3 and 4). The increase of $\mathrm{Cl}^{-}$indicates gradual absorption of dissolved chloride from bedrock and till.

In most of the samples collected in $1999, \mathrm{Ca}^{2+}$ and $\mathrm{Mg}^{2+}$ concentrations were much higher than those of $\mathrm{Na}^{+}$and $\mathrm{K}^{+}$ (Fig. 3). $\mathrm{Ca}^{2+}$ inputs to the Baishui glacier No. 1 catchment probably are dominantly from local (continental) sources. $\mathrm{K}^{+}$may originate from continental dust sources. $\mathrm{Mg}^{2+}$ has marine as well as continental sources. The data suggest that the impurities deposited in the glacier's system were mainly of a continental origin. Concentrations of $\mathrm{Mg}^{2+}, \mathrm{Ca}^{2+}$ and $\mathrm{K}^{+}$were higher in snow at high altitude than in that closer to the equilibrium line, but $\mathrm{Na}^{+}$and $\mathrm{Cl}^{-}$concentrations were lower at higher altitude. In general, the elution of $\mathrm{Ca}^{2+}$ and $\mathrm{Mg}^{2+}$ from a snowpack is more rapid than is that of $\mathrm{Na}^{+}$and $\mathrm{K}^{+}$(Davies and others, 1987). Thus, the decrease of ionic concentrations with decreasing altitude in the surface snow at Baishui glacier No. 1 may be the result of a longer period of melting at lower elevations. However, this cannot account for the pattern of $\mathrm{Na}^{+}$and $\mathrm{Cl}^{-}$concentrations. $\mathrm{SO}_{4}{ }^{2-}$ was detected in surface snow only at the highest site $(5000 \mathrm{~m})$. Most $\mathrm{SO}_{4}{ }^{2-}$ in snow is removed relatively rapidly in the early part of the melt season, and concentrations decrease particularly quickly at lower altitudes, where melting starts earlier (Raben and Theakstone, 1994). Early-season ionic elution of snow results in meltwater with a high ionic content. This has readily observed effects on river water (Tranter and others, 1987). The supraglacial meltwater formed from the leached snow is depleted of $\mathrm{SO}_{4}{ }^{2-}$ (Tranter and Raiswell, 1991). $\mathrm{SO}_{4}{ }^{2-}$ was detected in meltwater at Baishui glacier No. 1 only at lower altitudes; the concentrations were higher than in the one sample of summer rain in which $\mathrm{SO}_{4}{ }^{2-}$ was found (Fig. 3).

Concentrations of both $\mathrm{SO}_{4}{ }^{2-}$ and $\mathrm{NO}_{3}{ }^{-}$were much higher in the Baishui river than in the sources at higher altitudes, and they tended to increase as altitude decreased downstream (Fig. 4). This indicated that ionic enrichment occurred as a result of reactions with other materials. Hasnain and Thayyen (1999) believe that increased $\mathrm{SO}_{4}{ }^{2-}$ concentrations in river water discharging from Dokriani Glacier, Garhwal Himalaya, India, resulted from enhanced weathering of moraines by monsoonal rainfall.

Differences of conductivity of the samples of surface snow, rainfall and meltwater reflected the general trends apparent in the concentrations of individual ions (Fig. 3).

\section{RESULTS AND DISGUSSION}

Sampling in the Yulong mountain area in 2000 was more detailed than in 1999. $\delta^{18} \mathrm{O}$ of all samples was analyzed with a new Delta Plus mass spectrometer in the Laboratory of Ice Core and Cold Regions Environment.

\section{$\delta^{18} \mathrm{O}$ values in precipitation}

The $\delta^{18} \mathrm{O}$ values of winter accumulated snow, collected at the surface above $4800 \mathrm{~m}$ a.s.l. on 5 July, decreased with decreasing altitude (Table 1; Fig. 2). However, the $\delta^{18} \mathrm{O}$ values of a set of samples from about $30 \mathrm{~mm}$ of newly precipitated snow, collected at 4400-4750 $\mathrm{m}$ a.s.l. on 10 July when the temperature was lower $\left(-5-0^{\circ} \mathrm{C}\right)$, decreased with increasing altitude. The samples of surface snow from above $4800 \mathrm{~m}$ represent a winter precipitation event, and those from new accumulated snow below $4800 \mathrm{~m}$ represent a summer precipitation event. The $\delta^{18} \mathrm{O}$ values indicate different patterns of variation for winter and summer snowfalls.

Samples of summer rain were collected during a single precipitation event with a higher amount of precipitation (50 mm on average). Air temperature during sampling at $4700-3200 \mathrm{~m}$ a.s.l. was $10-20^{\circ} \mathrm{C}$. Summer rain was much more depleted of ${ }^{18} \mathrm{O}$ than were the winter and summer snow covers (Fig. 2). Four rainfall samples were collected at each of four locations (Fig. 2): Ganhaizi (3200-3270 m), the lower cableway station $(3330-3360 \mathrm{~m})$, the upper cableway station $(4490-4520 \mathrm{~m})$ and the glacier $(4550-4700 \mathrm{~m})$. The $\delta^{18} \mathrm{O}$ values were highest at Ganhaizi, where precipitation amount was lowest. The lowest values were for the samples collected at $4600-4700 \mathrm{~m}$, where precipitation amount was highest.

It is apparent that below $4800 \mathrm{~m}$ a.s.l. the higher $\delta^{18} \mathrm{O}$ values of summer snow correspond to lower-temperature conditions, and the lower values of summer rain correspond to higher-temperature conditions. The lowest values of 


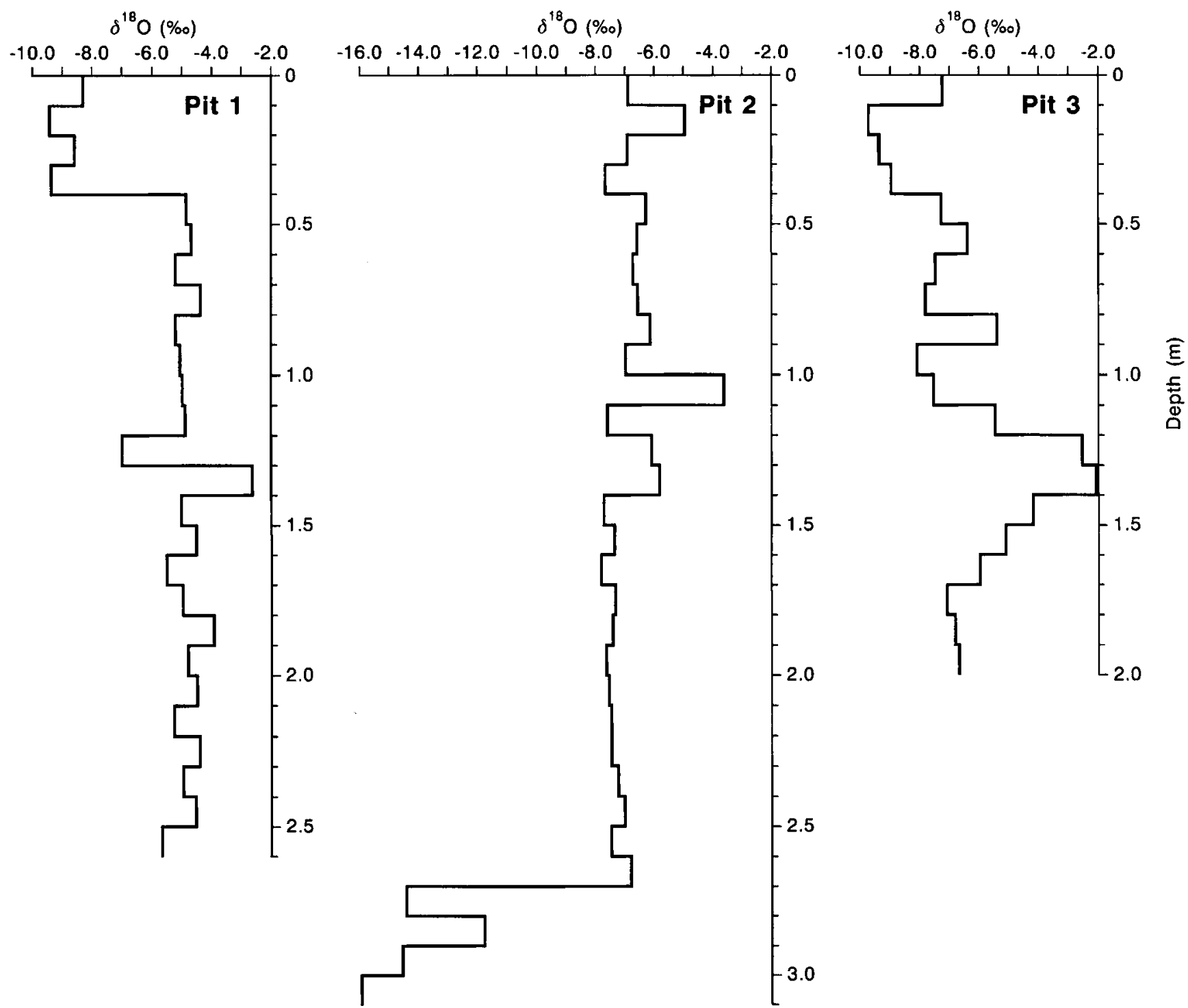

Fig. 5. $\delta^{18} \mathrm{O}$ values of snow samples in three pits excavated at Baishui glacier No. 1, July 2000. Pit 1 was at 5000 m a.s.l., pit 2 at $4900 \mathrm{~m}$ a.s.l., and pit 3 at $4750 \mathrm{~m}$ a.s.l.

summer-deposited snow at 4650-4750 m a.s.l. and of summer rain at 4600-4700m a.s.l. (Fig. 2) suggest the likely existence of a highest-precipitation-amount zone at $4600-4750 \mathrm{~m}$ in the glacier area. This irregular and varied pattern is characterized by an obvious reverse relation between $\delta^{18} \mathrm{O}$ values and temperature/precipitation amount in the prevailing summer monsoon period when samples were collected.

\section{$\delta^{18} \mathrm{O}$ values in snow pits}

Several days after the surface snow samples were collected, three pits were excavated in the accumulated snow on Baishui glacier No. 1, at 5000, 4900 and $4750 \mathrm{~m}$ a.s.l. (Fig. 1). Some melting occurred at the lowest site in the intervening period, but about $10 \mathrm{~mm}$ of new snow accumulated there. The amplitude of the isotopic variations at each pit site reflected the changeable climatic conditions during the period of snow accumulation. The $\delta^{18} \mathrm{O}$ values of most of the samples were higher than those of recently deposited surface snow and summer rain. It is apparent that snow deposited in winter, when precipitation amounts and air temperatures are lower, is less depleted of ${ }^{18} \mathrm{O}$ than is summer precipitation (Figs 2 and 5).

The highest site (pit 1, Fig. 1), at 5000 m, was excavated to a below-surface depth of $2.6 \mathrm{~m}$. The mean $\delta^{18} \mathrm{O}$ value of the 26 samples was $-5.49 \%$, and the coefficient of variation, a measure of the degree of heterogeneity, was -0.303 . The uppermost $0.4 \mathrm{~m}$ of the snow cover was more depleted of ${ }^{18} \mathrm{O}$ than was that beneath (Fig. 5). The maximum $\delta^{18} \mathrm{O}$ value $(-2.65 \%$ ) was at $1.3-1.4 \mathrm{~m}$ depth. Pit 2, at $4900 \mathrm{~m}$ (Fig. 1), was taken to a depth of $3.1 \mathrm{~m}$. $\delta^{18} \mathrm{O}$ values were generally lower than those at pit 1 . The mean $\delta^{18} \mathrm{O}$ value of the 31 samples was $-7.81 \%$, and the coefficient of variation was -0.346 . The maximum $\delta^{18} \mathrm{O}$ value $(-3.64 \%$ ) was at $1.0-1.1 \mathrm{~m}$ (Fig. 5$) .{ }^{18} \mathrm{O}$ depletion of the lowest four samples was markedly greater than that of the overlying snow, and the mean $\delta^{18} \mathrm{O}$ value of the uppermost $2.7 \mathrm{~m}$ of the snow cover was $-6.86 \%$ (coefficient of variation -0.136 ). Pit 3, at $4750 \mathrm{~m}$ a.s.l. (Fig. 1), was $2.0 \mathrm{~m}$ deep. $\delta^{18} \mathrm{O}$ values were more varied than in the two higher pits, with a maximum $(-2.07 \%$ o) at $1.3-1.4 \mathrm{~m}$ depth (Fig. 5). The mean of the 20 samples was $-6.60 \%$ and the coefficient of variation was -0.308

\section{$\delta^{18} \mathrm{O}$ values in glacial meltwater}

Ten samples of glacial meltwater were collected at 4530$4750 \mathrm{~m} . \delta^{18} \mathrm{O}$ values displayed a general increase with decreasing elevation (Table 1; Fig. 2). The mean value (-13.94\%o) was 
Table 1. Mean $\delta^{18} \mathrm{O}$ values in snow, meltwater, rain and glacier river water at Baishui glacier No. 1, Fuly 2000

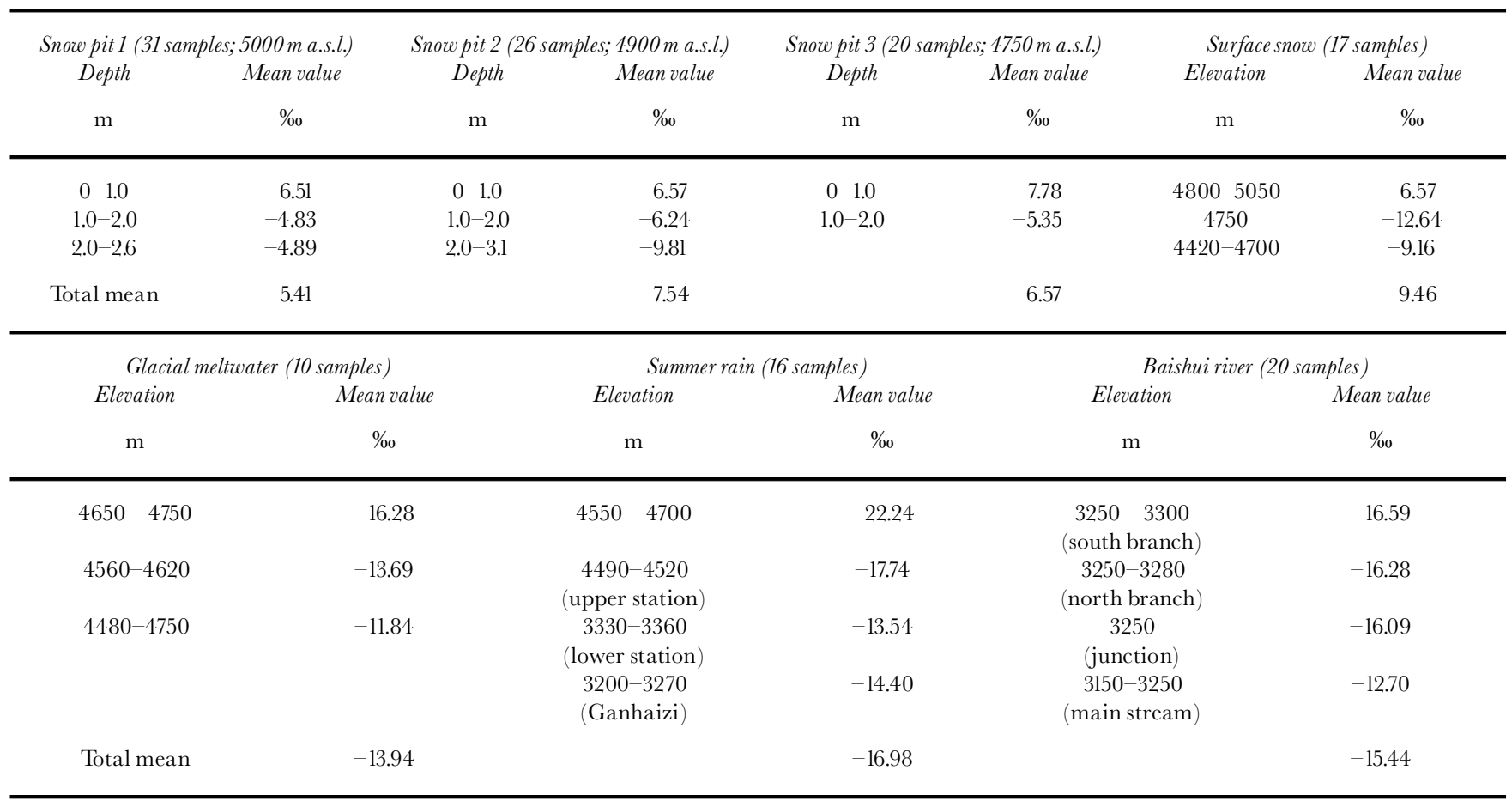

much lower than the means of winter-deposited snow $(-9.46$ $\%$ ) and accumulated snow at the pit sites $(-6.70 \%$ ), indicating that alternating isotopic depletion and fractionation occurred during the processes of snow-ice transformation, ablation, evaporation and supraglacial meltwater flow.

\section{$\delta^{18} \mathrm{O}$ values in the glacier-fed river}

Water samples were collected from various sections of the glacier-fed Baishui river at altitudes of 3300-3150 m. The mean of the five $\delta^{18} \mathrm{O}$ values of samples from the river's southern branch was $-16.59 \%$, and that of the three from the northern branch was $-16.28 \%$ (Table 1; Fig. 2). Below the junction at $3250 \mathrm{~m}$ a.s.l. (-16.09\%), values increased, suggesting that re-fractionation occurred during water flow, percolation, evaporation and contact with the river bed and ground-water. The highest $\delta^{18} \mathrm{O}$ value $(-11.75 \%$ ) was at the valley's end (Fig. 1). The mean value of the 20 Baishui river samples $(-15.44 \%$ ) was between those of glacial meltwater $(-13.94 \%)$ and summer rain $(-16.98 \%)$, demonstrating that the river water was a mixture of glacial meltwater and sources more depleted of ${ }^{18} \mathrm{O}$, including summer precipitation. Ground-water may enter the river, and further sampling and analysis is needed to calculate the relative contributions of meltwater, ground-water and precipitation to river discharge. The spatial and temporal variations of stable isotopes in the river may be used to identify the different sources of supply.

\section{CONGLUSIONS}

Yulong mountain is in a strong monsoon-climate area, influenced by moist air of a more distant marine origin in summer and by drier continental air masses in winter. The spatial distribution of oxygen isotopes and ions in snow and summer rain shows an irregular and varied pattern of these signals of precipitation in the region. There is an inverse relation between $\delta^{18} \mathrm{O}$ values and precipitation amount/air temperature in winter-deposited snow and summer precipitation sampled in both 1999 and 2000. From the isotopic data collected in 1999 and 2000, it is inferred that Yulong mountain may have a zone of highest precipitation at 4600-4700 m, as indicated by the lowest $\delta^{18} \mathrm{O}$ values of summer rain and snow.

The irregular spatial and temporal variations of the isotopic and ionic contents of snow, summer rain, meltwater and glacial runoff are controlled by varied monsoon climatic conditions on Yulong mountain. Both ionic changes and isotopic depletion or fractionation occur during processes of snow-ice transformation, meltwater formation and runoff, and contact with bedrock and till. However, the marked differences of $\delta^{18} \mathrm{O}$ values between winter-accumulated snow, glacial meltwater, summer precipitation and the glacier-fed river provide one of the best quantitative indices with which to differentiate between them. Variations of oxygen isotopes in glacier river water probably permit identification of different sources of supply, but this needs to be confirmed by more sampling and observation from each source of the river.

Sampling snow chemistry over a wide lateral and elevation range provides a basis for identifying discrete source areas and understanding the underlying processes responsible for the spatial variation in the chemical content of snow (Lyons and others, 1991). On the southern margin of the Qinghai-Tibetan Plateau, seasonal changes of dust transportation in the troposphere cause the highest $\mathrm{Ca}^{2+}, \mathrm{Mg}^{2+}$ and $\mathrm{SO}_{4}{ }^{2-}$ concentrations to occur in spring, with deposition during the peak dust storm activity, between mid-February and late May (Kang and others, 2000). At Baishui glacier No. 1, precipitation has a low impurity content. Most of the ions in the glacier's accumulation area are likely to come from nearby sources carried by moist air moving up the mountain slopes under the monsoon climate which controls the study area. 


\section{ACKNOWLEDGEMENTS}

The work reported here was supported by the HundredTalents Project (2002-43), Chinese Academy of Sciences, the Knowledge-Innovation Funds (210506 and 210019) from the Laboratory of Ice Core and Cold Regions Environment and the Cold and Arid Regions Environmental and Engineering Institute, the Chinese Natural Science Foundation (40071023) and the funds (KZCX-2-301 and G1998040800) from the Chinese Academy of Sciences. We are grateful for the support of the tourism company of Yulong mountain during the field seasons. Sun Weizhen, Sheng Wenkun, Li Feng Xia and Wang Xiaoxiang determined the $\delta^{18} \mathrm{O}$, cationic, anionic, $\mathrm{pH}$ and conductivity values in the laboratory. We thank N. Scarle for assistance with the figures.

\section{REFERENGES}

Dansgaard, W. 1964. Stable isotopes in precipitation. Tellus, 16(4), 436-468.

Davies, T. D. and 6 others. 1987. The removal of soluble ions from melting snowpacks. In Jones, H. G. and W. J. Orville-Thomas, eds. Seasonal snowcovers: physics, chemistry, hydrology. Dordrecht, etc., D. Reidel Publishing Co., 337-392. (NATO ASI Series C: Mathematical and Physical Sciences 211.)

Hasnain, S. I. and R. J. Thayyen. 1999. Controls on the major-ion chemistry of the Dokriani glacier meltwaters, Ganga basin, Garhwal Himalaya, India. F. Glaciol., 45(149), 87-92.

He Yuanqing and W.H. Theakstone. 1994. Climatic influence on the composition of snow cover at Austre Okstindbreen, Norway, 1989 and 1990. Ann. Glaciol., 19, 1-6.

He Yuanqing, Yao Tandong, Yang Meixue and Shen Yongping. 2000. [Contemporary significance of snow and ice indicated by the record in a shallow ice core from a temperate glacier in southwestern monsoon region.] 7. Glaciol. Geocryol., 22(3), 235-242 [In Chinese with English summary.]

He Yuanqing, Yao Tandong, Cheng Guodong and Yang Meixue. 2001a. Climatic records in a firn core from an alpine temperate glacier on Yulong mountain in southeastern Tibetan Plateau. Episodes, 24(1), 13-18.

He Yuanqing, W. H. Theakstone, Shi Yafeng and Yao Tandong. 2001b. The isotopic record at an alpine glacier and its implications for local climatic changes and isotopic homogenizationprocesses. F. Glaciol., 47(156), 147-151.

Hou Shugui and 6 others. 1999. Climatological significance of $\delta^{18} \mathrm{O}$ in precipitation and ice cores: a case study at the head of Ürümqi river, Tien Shan, China. 7. Glaciol., 45(151), 517-523.

Kang Shichang, C. P. Wake, Qin Dahe, P. A. Mayewski and Yao Tandong. 2000. Monsoon and dust signals recorded in Dasuopu glacier, Tibetan Plateau. J. Glaciol., 46(153), 222-226.

Kendall, C. and J. J. McDonnell. 1998. Isotope tracers in catchment hydrology. New York, Elsevier.

Li Jijun and Su Zhen, eds. 1996. [Glaciers in Hengduanshan range.] Beijing, Science Press. [In Chinese with English summary.]

Lyons, W. B., C. Wake and P. A. Mayewski. 1991. Chemistry of snow from high altitude, mid/low latitude glaciers. In Davies, T. D., M. Tranter and H. G. Jones, eds. Seasonal snowpacks: processes of compositional change. Berlin, etc., Springer-Verlag, 359-383. (NATO ASI Series G: Ecological Sciences 28.)

Moser, H. and W. Stichler. 1980. Environmental isotopes in ice and snow. In Fritz, P. and J. C. Fonte, eds. Handbook of environmental isotope geochemistry. Vol. 1. The terrestrial environment. Amsterdam, Elsevier Publishing Co., 141-178.
Raben, P. and W. H. Theakstone. 1994. Isotopic and ionic changes in a snow cover at different altitudes: observations at Austre Okstindbreen in 1991. Ann. Glaciol., 19, 85-91.

Raben, P. and W. H. Theakstone. 1998. Changes of ionic and oxygenisotopic composition of the snowpack at the glacier Austre Okstindbreen, Norway, 1995. Nord. Hydrol., 29 (1), 1-20.

Rozanski, K., L. Araguás-Araguás and R. Gonfiantini. 1993. Isotopic patterns in modern global precipitation. In Swart, P. K., K. C. Lohmann, J. A McKenzie and S. Savin, eds. Climate change in continental isotopic records. Washington, DC, American Geophysical Union, 1-36. (Geophysical Monograph 78.)

Shanley, J. B., C. Kendall, M. R. Albert and J. P. Hardy. 1995. Chemical and isotopic evolution of a layered eastern U.S. snowpack and its relation to stream-water composition. International Association of Hydrological Sciences Publication 228 (Symposium at Boulder 1995 - Biogeochemistry of Seasonally Snow-Covered Catchments), 329-338.

Stichler, W. 1987. Snowcover and snowmelt processes studied by means of environmental isotopes. In Jones, H. G. and W. J. Orville-Thomas, eds. Seasonal snowcovers: physics, chemistry, hydrology. Dordrecht, etc., D. Reidel Publishing Co., 673-726. (NATO ASI Series C: Mathematical and Physical Sciences 211.)

Su Zhen and Pu Jianchen. 1996. [The developing conditions, numbers and form of the glaciers in Hengduan mountain range.] In Li Jijun and $\mathrm{Su}$ Zhen, eds. Glaciers in Hengduanshan range 7. Beijing, Science Press, 1-25. [In Chinese with English summary.]

Su Zhen and Wang Lilun. 1996. [Characteristics of ablation, hydrology and hydrogeochemistry of glaciers in the Hengduan mountain range.] In $\mathrm{Li}$ Jijun and Su Zhen, eds. [Glaciers in Hengduanshanrange]. Beijing, Science Press, 70-110. [In Chinese with English summary.]

Theakstone, W. H. 1988. Temporal variations of isotopic composition of glacierriver water during summer: observations at Austre Okstindbreen, Okstindan, Norway. F. Glaciol., 34(118), 309-317.

Theakstone, W. H. and N.T. Knudsen. 1989. Temporal changes of glacier hydrological systems indicated by isotopic and related observations at Austre Okstindbreen, Okstindan, Norway, 1976-87. Ann. Glaciol., 13, 252-256.

Theakstone, W. H. and N.T. Knudsen. 1996. Oxygen isotope and ionic concentrations in glacier river water: multi-year observations in the Austre Okstindbreen basin, Norway. Nord. Hydrol., 27(2), 101-116.

Tian Lide, Yao Tandong and $\mathrm{Pu}$ Jianchen. 1997. [Characteristic of $\delta^{18} \mathrm{O}$ in summer precipitation at Lhasa.] f. Glaciol. Geocryol., 19(4), 295-301. [In Chinese with English summary.]

Tranter, M. and R. Raiswell. 1991. The composition of the englacial and subglacial component in bulk meltwaters draining the Gornergletscher, Switzerland. 7. Glaciol., 37(125), 59-66.

Tranter, M. and 6 others. 1987. Changes in streamwater chemistry during snowmelt. In Jones, H.G. and W. J. Orville-Thomas, eds. Seasonal snowcovers: physics, chemistry, hydrology. Dordrecht, etc., D. Reidel Publishing Co., 575-597. (NATO ASI Series C: Mathematical and Physical Sciences 211.)

Tranter, M., G. H. Brown, A. J. Hodson and A. M. Gurnell. 1996. Hydrochemistry as an indicator of subglacial drainage system structure: a comparison of Alpine and sub-polar environments. Hydrol. Processes, $\mathbf{1 0}(4), 541-556$.

Wagenbach, D. 1989. Environmental records in alpine glaciers. In Oeschger, H. and C.C. Langway, Jr, eds. The environmental record in glaciers and ice sheets. Chichester, etc., John Wiley and Sons, 69-83.

Yao Tandong, Ding Liangfu and Pu Jianchen. 1991. [ $\delta^{18} \mathrm{O}$ in snowfall of Tanggula Mts. (Qinghai-Tibetan Plateau) and its relationship with sources of precipitation.] Chin. Sci. Bull., 36(20), 1570-1573. [In Chinese.]

Zhang Xinping and Yao Tandong. 1995. [Relations between weather systems affecting Tibetan Plateau and oxygen isotope in precipitation.] f. Glaciol. Geocryol., 17 (2), 125-131. [In Chinese with English summary.] 